\title{
A Preliminary Study on Standardizing the K-Bayley- III Expressive Communication Scale
}

\author{
Ji Yun Lee ${ }^{a}$, Young Tae Kim ${ }^{\mathrm{b}}$, Hee Jeong Bang ${ }^{\mathrm{c}}$, Soon Hang Lee \\ ${ }^{a}$ Graduate Program in Developmental Psychology, Ewha Womans University, Seoul, Korea \\ ${ }^{b}$ Department of Communication Disorders, Ewha Womans University, Seoul, Korea \\ 'Department of Psychology, Ewha Womans University, Seoul, Korea
}

\author{
Correspondence: Bang Hee Jeong, PhD \\ Department of Psychology, Ewha Womans \\ University, 52 Ewhayeodae-gil, Seodaemun-gu, \\ Seoul 120-750, Korea, \\ Tel: $+82-2-3277-2644$ \\ Fax: + 82-2-3277-4010 \\ E-mail: hjbang@ewha.ac.kr \\ Received: July 4, 2014 \\ Revised: August 23, 2014 \\ Accepted: September 13, 2014
}

This work was supported by the research fund of Social Service R\&D of Korean Ministry of Health and Welfare (2012).

This article is based on a part of the first author's master's thesis from Ewha Womans University (2014).

\begin{abstract}
Objectives: The purpose of this is a preliminary study on developing the Korean version of the Expressive Communication Scale of Bayley-III (K-Bayley-III) by analyzing the components and difficulty of each item and examining whether the items are socio-culturally and linguistically appropriate for assessing the expressive language skills of Korean young children. Methods: A total of 48 original items and 8 additional items were translated, reviewed, modified, removed, or added to the latest version of the K-Bayley-III expressive communication (EC) scale and were used to assess the expressive language skills of 373 Korean infants and toddlers between ages 16 days and 42 months, 15 days residing in Seoul and Gyeonggi province. Results: Overall, items were appropriately placed in the order of difficulty, and those with inadequate difficulty levels were replaced, modified, or removed. Most baseline items showed a $90 \%$ pass rate. Inter-item consistency showed acceptable levels and items were highly reliable in terms of test-retest reliability and inter-rater reliability. Items from the EC scale showed significant correlations with the Language scale, RC scale, and motor scales, and also demonstrated high levels of content validity and concurrent validity. Conclusion: These results indicate that the K-Bayley-III Expressive Communication scale could be used to assess the general expressive language development of Korean infants and toddlers. Items that did not reflect the characteristics of Korean language development were suggested to be replaced or modified in order to develop a final version of the standardized K-Bayley-III expressive scale.
\end{abstract}

Keywords: K-Bayley-III, Expressive Communication, Item analysis, Reliability, Validity
이차 언어장애는 발달장애나 뇌 손상 등으로 인해 이차적으로 야기되는 언어장애로, 언어 문제로 내원하는 아동의 상당수가 이 차 언어장애를 가진 영유아이다(Pence \& Justice, 2008). 이차 언어 장애를 가진 영아들은 선천적으로 언어기제가 취약하므로 생의 첫 1 년 이내부터 언어문제를 보이곤 한다. 전형적으로 영아기에는 옹 알이나 제스처와 같이 결정적인 언어적 전조를 획득하는 것에서 지체를 보이며, 걸음마기와 학령전기에서는 첫 낱말의 발화, 낱말 을 조합하여 문장 만들기에서의 지체를 순차적으로 나타낸다(Pence \& Justice, 2008). 한편, 영유아기는 발달의 가소성이 가장 커서 조 기 중재로 인한 교육 및 치료 효과가 가장 높은 시기이다. 이에 따라 영유아기에 발생할 수 있는 다양한 발달적 문제들을 범주화하고
이를 조기에 판별 및 진단할 수 있는 검사도구의 필요성이 계속 대 두되어 왔다. 또한 영유아기는 전 생애 발달의 출발점으로 신체, 인 지, 언어, 정서, 생활습관 등 모든 요소가 기본적으로 발달하므로 발달 전 영역에 걸친 균형 잡힌 성장과 발달과업 성취가 중요한 시 기이다. 특히 한 영역에서의 발달문제는 다른 영역의 발달에 영향 을 미치므로, 영유아기 발달에 대한 접근은 영역별 개별적 접근보 다는 다학제적이고 통합적인 관점에서 이루어져야 한다(Aylward, 2009).

현재 한국에서 시행되고 있는 표준화된 영유아 언어 진단 검사 로는 영유아 언어발달 검사(Sequenced Language Scale for Infant, SELSI; Kim, Kim, Yoon, \& Kim, 2003), 한국판 맥아더-베이츠 의 
사소통발달평가 (Korean-MacArthur-Bates-Communicative Development Inventory, K M-B CDI; Pae \& Kwak, 2011), 취학 전 아동 의 수용 언어 및 표현 언어발달 척도(Preschool Receptive-Expressive Communication Scale, PRES; Kim, Sung, \& Lee, 2003) 등이 있다. 그러나 이들 검사들 모두 영유아 시기의 언어 문제를 포괄적 이면서도 통합적으로 측정하기에는 다음과 같은 한계점을 지니고 있다. 먼저, SELSI와 K M-B CDI는 주 양육자의 보고에 의해 이루어 지는 부모 보고형 검사이므로 정밀하고 객관적인 판별을 요하는 언 어 진단 평가로서는 한계를 지니고 있다. 반면, $\mathrm{PRES}$ 는 전문 검사 자에 의해 실시되는 검사이기는 하지만 19 개월 이전의 언어문제를 조기에 판별 및 진단하는 데 한계를 지니고 있다. 따라서 이들 검사 도구들은 모두 언어 장애 아동 평가에 요구되는 발달 전반에 걸친 종합적이고 통합적인 정보를 제시해주지 못한다는 한계점을 지니 고 있다. 물론, 통합적인 관점에서 언어능력을 측정하는 표준화 검 사도구들도 존재하지만, 정밀한 언어 진단과 중재를 위한 기초 자 료로 사용하기에는 정보가 매우 부족하다.

현재 우리나라에서 표준화된 종합발달 진단검사도구로는 '한국 형 베일리 영유아 발달검사 제2판(Korean Bayley Scales of Infant Development-II, K-BSID-II; Cho \& Park, 2004)'이 있다. 그러나 KBSID-II는 인지척도 내에서 인지(cognition)와 언어(language) 능 력을 혼합하여 측정하고 있어서 언어 능력만을 정밀하게 평가하는 데 한계점이 있고, 20 여 년 전에 개발된 베일리 영유아 발달 검사 제 2판(BSID-II; Bayley, 1993)을 표준화한 검사이기에, 21세기 전후해 서 급속하게 발전된 영유아 발달 연구의 흐름을 포괄하지 못하여 한계점을 지니고 있다.

베일리 영유아 발달검사 제3판(Bayley Scales of Infant and Toddler Development, Bayley-III; Bayley, 2006)은 16일에서 42개월 15 일 영유아를 대상으로 현재 발달 기능을 전문가에 의해 측정하는 종합발달진단검사이다. Bayley-III에서는 정신척도 내의 '언어' 영 역을 따로 분리해 냈다. Bayley-III는 장애인교육법(The Individuals with Disabilities Education Improvement Act of 2004, IDEA)에 따라 인지, 언어(수용언어, 표현언어), 운동(대근육 운동, 소근육 운 동), 정서-사회성, 적응 행동의 5 가지 발달영역을 측정하고 있어, 아 동의 발달상태에 대한 다학제적 검사 실시 및 진단이 가능하고, 이 를 통해 다양한 발달 영역에 대한 종합적인 정보를 제공해줄 뿐만 아니라 영역 간의 상대적인 강점과 약점을 통합적으로 파악하는 데도 유용하다(Bayley, 2006). 현재 Bayley-III는 전 세계적으로 가 장 널리 사용되고 있는 종합발달진단검사로서, 2006년에 출판된 이래 미국(Bayley, 2006), 영국(Moore, Johnson, Haider, Hennessy, \& Marlow, 2012), 캐나다(Acton et al., 2011), 독일(Reuner, Fields,
Wittke, Löpprich, \& Pietz, 2013), 스페인(Esteban et al., 2010), 호주 (Walker, Badawi, Halliday, \& Laing, 2010), 대만(Yu et al., 2013) 등 에서 표준화를 위한 비교문화 연구가 활발히 진행되고 있다.

Bayley-III 언어척도는 통합적인 관점에서 수용언어(receptive communication, $\mathrm{RC}$ )와 표현언어(expressive communication, EC) 능력을 각각 정밀하게 평가할 수 있다는 점에서 매우 유용한 검사 도구이다. 이 중 Bayley-III 표현언어척도는 발달 시기에 따라 크게 4가지 능력을 중심으로 측정하는데, 첫 번째는 소리내기(cooing), 옹알이(babbling)와 같은 발성하는 능력을 확인하는 음운론적인 요소를 측정하는 문항, 두 번째는 성인이 말한 소리나 단어를 모방 하고 단어를 사용하는 능력을 측정하는 의미론적인 요소의 문항, 세 번째는 절, 구, 문장으로 말하는 능력을 측정하는 형태 및 구문 론적인 요소의 문항, 그리고 마지막으로는 타인과의 자발적인 대화 를 하거나 제스처 능력과 같은 화용론적인 측면을 측정하는 문항 들로 구성되어 있다(Bayley, 2006).

하지만 Bayley-III 표현언어척도를 한국 영유아에게 적용하기 어 려운 이유는 한국 문화에서 한국어를 습득하는 과정은 영어권 문 화에서 영어를 습득하는 과정과 동일하지 않기 때문이다. 이를 위 해 Bayley-III를 한국어 및 한국 문화에 적합하게 표준화하는 과정 에서는 언어의 다섯 요소(음운론, 의미론, 형태 및 구문론, 화용론) 의 문화 차이를 고려하면서 각 문항을 검토하였다. 먼저, 음운론적 인 측면에서 영아가 말소리 또는 음소에 대한 체계 및 규칙을 습득 하는 과정에서 언어적 차이를 고려하였다. 예를 들면, 영어에서는 존재하는 음소지만 한국어에는 존재하지 않는 음소들이 있으며(/f, $\mathrm{v}, \mathrm{th} /)$, 반대로 한국어에서는 존재하지만 영어에서는 존재하지 않 는 음소들이 있다(/ㅃ,뜨,ㅉ/). 또한 두 언어에 존재하는 음소라도 습득시기가 언어에 따라 차이가 있는 경우도 있다. 둘째, 문장 또는 어휘의 의미 이해와 관련된 의미론적인 측면에서 영어와 한국어 간에 영유아가 습득하는 어휘 순서에서의 차이를 고려하였다. 예 를 들어, 미국 영아들이 초기에 산출하는 'down', 'up' 등의 어휘들 은 한국 영아의 초기 산출어에는 포함되어 있지 않다(Chang, 2004b). 또한, 초기 산출하는 문법적 기능어 상위 20 위 안에 미국 영유아들 은 'mine, me, you, I, my' 등의 다양한 인칭 대명사 발화가 포함되 어 있는 반면, 한국 영유아들은 인칭대명사보다는 ‘이거’라는 지시 대명사 발화가 상위에 포함되었으며, '나라는 1 인칭 대명사만이 포 함되어 있었다(Chang, 2004b). 이러한 언어 문화적 차이를 고려하 면서 한국 영아에게서만 독특하게 나타나는 초기 발화어의 특성 을 검토하였다. 셋째, 형태론 및 구문론적인 측면에서는 형태소들 의 결합을 통해 단어, 구, 절, 문장의 체계 및 규칙을 형성하는데, 한 국어와 영어의 문장 구성요소 및 문법 체계가 확연하게 다르기에 
아동이 표현하는 문장의 형태가 전혀 다르다. 예를 들면, 영어 발화 에서는 현재 진행형이나 소유격, 복수형 등의 형태소 발달이 중요 한 이정표로 여겨지는 반면에, 한국어에서는 조사나 어미 발달이 더욱 중요한 문법 발달의 이정표로 제안되기에 이러한 차이를 고려 하였다(Cho, 1982; Kang, 2008; Kim et al., 2003). 넷째, 화용론적인 측면에서 상대방의 의사소통 의도를 적절히 파악하고 반응하기 위 해 요구되는 문화마다 서로 다른 언어규칙, 즉 사회.인지적 능력을 고려하였다.

따라서, 본 연구에서는 한국어 발달 및 사회문화적 맥락에 적절 하게 Bayley-III 표현언어척도 예비연구본을 제작하고 국내 적용의 가능성을 모색해 보고자 하였다. 먼저, 한국 영유아의 언어발달을 적절히 반영하는지 문항 내용을 확인하여 한국어 및 문화적 특성 에 적절하게 문항 수정, 삭제 및 추가작업을 통해 K-Bayley-III 표현 언어척도 예비연구본을 마련하고, 이후 문항 분석 및 신뢰도, 타당 도 검증을 통해 K-Bayley-III 유용성을 살펴보고자 하였다.

\section{연구 방법}

\section{연구대상}

본 연구는 서울 및 경기 지역을 포함한 수도권에 거주하는 생후 16 일-42개월 15 일의 영유아 373 명을 대상으로 진행되었다. 미국의 예비연구 분포와 동일하게 17 개 월령집단을 구분하여 각 월령단계 별로 20 명 내외로 하여 성별에 따라 비교적 고르게 분포되도록 표 집하였다. 또한 어머니 학력도 서울 및 경기 지역 20-45세 여성의 인 구통계학적 분포에 따라 고르게 분포하도록 표집하였는데, 고졸 이 하 $27 \%$, 대졸 이하 $65 \%$, 대학원 재학 이상 $8 \%$ 로 구성하였다. 최종 적으로 분석에 사용된 자료에서 남아는 191명(51\%), 여아는 182명 (49\%), 총 373명이었다. 월령단계별 및 성별에 따른 표집 구성은 $\mathrm{Ta}-$ ble 1 에 제시하였다.

\section{연구절차}

원검사의 번안 절차

K-Bayley-III 표현언어척도 예비연구본을 개발하기 위하여 먼저 영어로 된 Bayley-III를 한국어로 번안하는 작업을 거쳤다. 번안 작 업은 5 단계에 거쳐 이루어졌다. 먼저, 발달심리전공 석사과정 학생 들이 도구의 기초적인 번역 작업을 착수하였다. 이후 표준화된 언 어발달검사 및 문헌연구를 통해 언어 관련 전문용어의 한국어 번 안을 수정하였다. 2 단계에서는, 언어병리 및 심리학을 이중 전공한 석사생과 통번역 대학원생에 의한 역번역이 이루어졌다. 3 단계에서 는, 언어병리전공 교수, 심리언어전공 교수, 발달심리전공 교수로 이
Table 1. Descriptive statistics of the expressive communication performance by age groups

\begin{tabular}{|c|c|c|c|c|c|c|}
\hline \multirow{2}{*}{$\begin{array}{l}\text { Age } \\
\text { level }\end{array}$} & \multirow{2}{*}{$\begin{array}{c}\text { Age } \\
\text { (mo; day) }\end{array}$} & \multicolumn{3}{|c|}{ No. of participants } & \multirow{2}{*}{$\begin{array}{l}\text { Mean raw } \\
\text { score }\end{array}$} & \multirow{2}{*}{ SD } \\
\hline & & Male & Female & Total & & \\
\hline$A$ & $0 ; 16-1 ; 15$ & 4 & 0 & 4 & 3.75 & 0.96 \\
\hline B & $1 ; 16-2 ; 15$ & 6 & 5 & 11 & 4.64 & 1.29 \\
\hline C & 2;16-3;15 & 13 & 10 & 23 & 5.09 & 1.13 \\
\hline D & $3 ; 16-4 ; 15$ & 11 & 10 & 21 & 5.38 & 0.97 \\
\hline$E$ & $4 ; 16-5 ; 15$ & 11 & 10 & 21 & 6.52 & 1.08 \\
\hline $\mathrm{F}$ & 5;16-6;15 & 9 & 12 & 21 & 6.67 & 1.77 \\
\hline G & $6 ; 16-8 ; 30$ & 11 & 11 & 22 & 9.50 & 4.02 \\
\hline $\mathrm{H}$ & $9 ; 0-10 ; 30$ & 12 & 12 & 24 & 11.54 & 2.81 \\
\hline I & $11 ; 0-13 ; 15$ & 9 & 11 & 20 & 13.40 & 2.58 \\
\hline$J$ & $13 ; 16-16 ; 15$ & 11 & 12 & 23 & 13.96 & 5.10 \\
\hline K & $16 ; 16-19 ; 15$ & 13 & 11 & 24 & 18.71 & 3.39 \\
\hline L & $19 ; 16-22 ; 15$ & 12 & 10 & 22 & 24.09 & 3.74 \\
\hline M & $22 ; 16-25 ; 15$ & 10 & 11 & 21 & 27.38 & 6.83 \\
\hline $\mathrm{N}$ & $25 ; 16-28 ; 15$ & 8 & 12 & 20 & 31.65 & 5.45 \\
\hline 0 & $28 ; 16-32 ; 30$ & 13 & 14 & 27 & 34.67 & 7.14 \\
\hline$P$ & $33 ; 0-38 ; 30$ & 23 & 18 & 41 & 38.22 & 6.56 \\
\hline 0 & $39 ; 0-42 ; 15$ & 15 & 13 & 28 & 40.68 & 4.62 \\
\hline Total & $0 ; 16-42 ; 15$ & 191 & 182 & 373 & 17.40 & 3.50 \\
\hline
\end{tabular}

루어진 전문가 자문회의를 통해 언어체계 및 문화 차이로 인한 문 항 수정 및 삭제가 불가피한 문항을 확인하고 새로운 문항을 추가 하였다. 4단계는, 한국 영유아들에게 친숙하지 않은 단어(예, mopping)나 상황(예, 미국택시)의 사진을 한국 문화에 적절하게 수정 하였다. 5 단계에서는 현장 조사를 실시하였다. 서울 시내 소재한 어 린이집에 방문하여 약 10 명의 영유아를 대상으로 번안된 문항, 수 정 문항, 보충 문항을 실시하여 아이들에게 친숙하지 않은 용어 및 실시 지침서 및 채점 관련 점검사항들을 확인하였다. 이 과정에서 언어 및 발달심리 전문가의 자문에 따라 새롭게 수정 및 보완되는 내용들을 지침서 및 기록지에 적용하였다. 이상과 같이 문항의 최 종점검을 진행한 후, K-Bayley-III 표현언어척도의 예비연구본을 완 성하였다.

\section{K-Bayley-III 표현언어척도 예비연구본 제작}

번안 과정에서 원검사의 문항을 생략, 수정, 추가하여 K-BayleyIII 표현언어척도 예비연구본을 제작하였다. 생략, 수정, 추가된 문 항의 세부적인 내용은 Appendix에 제시하였다. 최종적인 K-Bayley-III 표현언어척도 예비연구본의 문항 구성 및 내용을 세부적으 로 살펴보았을 때, 음운론, 의미론, 형태론, 통사론, 화용론에 따라 균형 있게 구성되어 있다. 조음음운능력을 평가하는 문항이 10 문 항, 단어 표현을 다룬 문항이 15 문항, 다양한 단어 형태 사용을 평 
가하는 문항은 4 문항, 문장 사용을 다룬 문항이 11 문항, 그리고 화 용적인 상호작용 및 발화를 다룬 문항이 8 문항으로, 문항들이 언 어의 다섯 요소에 따라 고루 분포되어 있으며 각 월령 단계에서 중 요시 여겨지는 언어 요소에 따라 문항이 배치되었다.

\section{검사자 훈련}

본 연구는 보건복지부 한국형 영유아발달검사 서비스 개발 연구 의 일부로서, 2013년 5-7월까지 총 3차례에 걸쳐 검사자를 모집하였 다. 심리학, 언어병리학, 특수교육학, 재활 의학, 소아 의학 관련 분 야에 종사하는 석사과정 이상의 검사자 86 명이 지원 및 추천을 통 해 선발되었다. 검사자 훈련은 검사 전반에 대한 오리엔테이션과 검 사 실시 및 채점 방법에 대한 강의, 그리고 모의 검사 실습 내용으로 구성되었다. 훈련을 마친 검사자들은 숙련된 검사자들의 실제 검사 현장을 관찰하는 과정을 통해 실제 검사 및 채점에 대한 숙지가 이 루어지도록 하였다. 연구가 진행되는 동안 격주로 집단 슈퍼비전 모 임을 통해 검사 실시 및 채점 과정에 대한 지속적인 슈퍼비전을 제 공하였다.

\section{참여자 모집 및 검사 실시}

예비연구를 위한 자료 수집은 2013년 5-8월에 걸쳐 진행되었다. 검사 실시는 서울 $\mathrm{E}$ 병원 및 $\mathrm{E}$ 대학교 검사실에서 이루어졌다. 표현 언어척도 검사에 소요되는 시간은 6 개월 이전 영아의 경우 5-10분, $6-18$ 개월의 경우 $15-20$ 분, 18 개월 이후는 20-30분 정도이다. A-C단 계 신생아(생후 16 일-4개월 15일)에 대해서는 방문 검사를 병행하 였다. 어린이집, 서울 소재 소아과, 육아 인터넷 카페 등에 참여 홍보 문을 게시하였으며, 참여를 희망하는 영유아의 보호자가 인터넷 홈페이지를 통해 직접 참가신청을 하는 방식으로 참여자를 모집하 였다. 참여 신청시 표집 프로그램을 사용하여 아동의 연령, 성별, 어 머니 학력 및 거주 지역을 입력하도록 하였고 인구학적 분포에 따 라 미리 설정된 인원만큼만 예약할 수 있게 하였다.

\section{연구도구}

\section{K-Bayley-III 표현언어척도 예비연구본}

본 연구에서는 한국형 베일리 영유아 발달검사 3 판 (K-BayleyIII) 표현언어척도 예비연구본을 사용하였다. 표현언어척도는 원 문 항 48 개 문항, 추가 문항 8 개 문항으로 총 56 개 문항으로 구성되어 있다. 각 문항은 통과하면 1점, 실패하면 0 점으로 채점한다. Table 2 에 제시된 것처럼, 17 개의 연령 단계별로 시작점(start point)이 있고 시작규칙과 중지규칙에 따라서 실시한다. 시작규칙은 시작점 문항 (예를 들어, P단계의 경우, 27번이 시작문항)을 포함하여 연속적으
Table 2. Difficulty for items of the expressive communication scale

\begin{tabular}{|c|c|c|c|}
\hline No & $\begin{array}{l}\text { Start } \\
\text { point }\end{array}$ & Item & $b$ \\
\hline 3 & $E / F / G / H$ & Vocalizes mood & -4.047 \\
\hline 4 & & Undifferentiated nasal sound & -2.119 \\
\hline 5 & & Social vocalizing or laughing & -2.322 \\
\hline 6 & & Two vowel sounds & -1.080 \\
\hline 7 & I & Gets attention & -.895 \\
\hline 8 & & Two consonant sounds & -.601 \\
\hline 9 & & Uses gestures & -.729 \\
\hline 10 & J & Consonant-vowel combination series: 1 combination & -.475 \\
\hline 11 & & Participates in play routine & -.645 \\
\hline 12 & & Jabbers expressively & -.541 \\
\hline 13 & & Consonant-vowel combination series: 4 combinations & -.106 \\
\hline 14 & K & Uses one-word approximations & -.278 \\
\hline 15 & & Directs attention of others & -.415 \\
\hline 16 & & Imitates word & -.078 \\
\hline 17 & L & Initiates play interaction & -.309 \\
\hline 18 & & Uses words appropriately series: 2 words & -.136 \\
\hline 19 & & Uses word to make wants known & .014 \\
\hline 20 & $\mathrm{M} / \mathrm{N}$ & Names object series: 1 object & .264 \\
\hline 21 & & Combines word and gesture & .041 \\
\hline 22 & & Names picture series: 1 picture & .255 \\
\hline 23 & 0 & Uses words appropriately series: 8 words & .191 \\
\hline 24 & & Answers yes or no verbally in response to questions & .140 \\
\hline 25 & & Imitates a two-word utterance & .533 \\
\hline 26 & & Uses a two-word utterance & .428 \\
\hline 27 & $P$ & names object series: 3 objects & .560 \\
\hline 28 & & Names picture series: 5 pictures & .592 \\
\hline 29 & & Uses multiple-word utterances & .752 \\
\hline 30 & 0 & Uses pronouns & .521 \\
\hline 31 & & Names action picture series: 1 picture & .657 \\
\hline 32 & & Poses multiple-word questions & .760 \\
\hline 33 & & Makes a contingent utterance & .813 \\
\hline 34 & & Uses verb + ing & 1.012 \\
\hline 35 & & Names action picture series: 3 pictures & .866 \\
\hline 36 & & Uses different word combinations & .909 \\
\hline 37 & & Names action picture series: 5 pictures & 1.062 \\
\hline 39 & & Answers what and where questions & 1.078 \\
\hline 41 & & Names 4 colors & 1.161 \\
\hline 42 & & Answers questions logically (related to functions) & 1.141 \\
\hline 43 & & Tells how an object is used & 1.700 \\
\hline 44 & & Uses prepositions & 1.993 \\
\hline 45 & & Uses present progressive form & 1.212 \\
\hline 46 & & Describes pictures series: uses 4-5 word sentences & 1.700 \\
\hline 47 & & Describes pictures series: uses past tense & 1.825 \\
\hline 48 & & Describes pictures series: uses future tense & 1.840 \\
\hline
\end{tabular}

$b=$ difficulty parameter.

로 3 개 문항을 통과하면 그 문항을 기저선으로 하여 이후 문항을 계속해서 실시할 수 있고, 만약 연속적으로 3 개 문항에서 통과하지 못하면 이전 월령 시작점(예, O단계 시작문항이 23번)으로 이동한 
다. 중지규칙이란 연속으로 5 개 문항을 실패하면 검사 실시를 종료 하는 것을 말한다. 시작점 이후로 통과한 문항 수와 시작점 이전의 기저선 점수를 더하여 원점수를 산출한다.

\section{취학 전 아동의 수용언어 및 표현언어 척도(PRES)}

표현언어척도의 공인타당도를 확인하기 위해, 취학 전 아동의 수 용언어 및 표현언어 척도 PRES (Kim et al., 2003)의 표현언어척도 를 사용하였다. PRES는 기존의 검증된 표준화 언어검사도구로 광 범위한 언어 영역을 모두 평가할 수 있다.

\section{한국판 맥아더-베이츠 의사소통발달평가(K M-B CDI)}

공인타당도를 확인하기 위한 또 다른 언어검사로는 한국판 맥아 더-베이츠 의사소통발달평가(K M-B CDI; Pae \& Kwak, 2011) 중 유 아용표현어휘를 사용하여 살펴보았다. KM-B CDI 표현어휘는아동 이사용하는 어휘를 위주로 직접 체크할수 있어 신뢰로운 검사이다.

\section{자료 분석}

본 연구에서 수집된 자료는 SPSS Statistics version 21.0 (IBM, Armonk, NY, USA)과 BILOG-MG 3 (Scientific Software International Inc., Skokie, IL, USA)를 사용하였다. 본 연구에서는 Bayesian expected a posteriori (EAP) 방식으로 문항반응이론에 의한 문 항 모수치를 추정하였고, 고전검사이론에 기반하여 월령 단계별 시 작문항 및 기저선 문항의 문항통과율을 알아보았다. 또한 문항내 적합치도 알아보기 위해 Cronbach $\alpha$ 를 연령대별로 산출하였으며, 검사-재검사 신뢰도 및 평정자 간 신뢰도를 위해 intraclass 상관계 수를 산출하였다. 그리고 구인타당도와 공인타당도 검증을 위하여 Pearson 상관계수를 산출하였다.

\section{연구 결과}

\section{기초통계분석}

K-Bayley-III 표현언어척도가 월령 단계별, 성별, 어머니 학력에 따른 영유아 수행의 변화를 살펴보았다. 먼저, 월령에 따른 수행의 변화를 알아보기 위하여 월령 단계별 평균과 표준편차를 살펴보았 다. Table 1 에서 나타내는 것과 같이 모든 월령 단계의 전체 평균 원 점수는 $17.40(\mathrm{SD}=3.5)$ 으로 나타났다. 또 월령이 증가할수록 표현 언어척도 원점수의 평균 점수도 높아지고 있음을 확인할 수 있다. 이는 본 검사가 연령이 증가함에 따라 발달하는 영유아의 표현언어 척도 능력을 적절하게 측정하고 있음을 보여준다. 두 번째로, 성별 에 따른 차이를 알아본 결과, 남아의 평균은 $18.13(\mathrm{SD}=12.89)$ 으
로, 여자의 평균인 $19.96(\mathrm{SD}=13.51)$ 과 표현언어능력 간의 유의미 한 차이가 없었다 $(t=1.698, p>.05)$. 세 번째로, 어머니 학력에 따른 차이를 살펴본 결과, 고졸인 어머니의 아동 평균 원점수는 20.67 (SD =13.42), 대졸인 어머니의 아동은 평균 $19.21(\mathrm{SD}=12.90)$, 그 리고 대학원 이상 어머니의 아동은 평균 $19.49(\mathrm{SD}=13.05)$ 로, 어머 니 학력에 따른 영유아의 표현언어능력에서도 유의미한 차이가 없 었다 $(t=.271, p>.05)$.

\section{문항 분석}

K-Bayley-III 표현언어척도의 문항분석을 위해 전반적인 문항 난 이도 및 월령별 문항통과율, 시작 문항 및 기저선 문항의 통과율, 시 리즈 문항의 난이도, 보충문항의 난이도를 살펴보았다.

\section{문항난이도 분석}

K-Bayley-III는 집단의 규준에 비추어 상대적 서열을 판단하는 규준검사에 해당하므로, 검사 문항들이 난이도 수준에 따라서 다 양하게 분포되어 있고 순차적으로 배치되어 있어야 한다(Sung, 2004). K-Bayley-III 표현언어척도 문항이 이러한 특성을 나타내는 지 확인하기 위하여 문항반응이론을 적용하여 분석하였다. 문항 반응이론은 문항특성곡선에서 추정된 문항 난이도 모수에 따라 문항의 고유한 특성을 결정하므로 표본 특성에 따라 검사 문항들 이 영향을 받지 않는 장점이 있다(Sung, 2001). 우선, 분석 전에 표 현언어척도의 몇몇 문항은 난이도 분석에서 제외되었다. 검사에 참 여한 모든 아동이 1 번 문항(미분화된 목소리 내기)과 2 번 문항(사 회적 미소짓기)을 통과하여 변량이 산출되지 않아서 분석에서 제 외되었다.

\section{원문항의 문항난이도 분석}

표현언어척도의 원문항 총 44 개 문항을 대상으로 한 문항난이도 분석 결과는 Table 2에 제시하였다. Table 2에 제시된 바와 같이, $\mathrm{K}-$ Bayley-III 표현언어척도의 문항들은 전체적으로 쉬운 문항에서부 터 어려운 문항까지 적절히 구성되어 있었다. 즉, 검사초반에는 난 이도가 매우 쉬운 문항부터 난이도가 매우 어려운 48 번 문항까지 난이도가 점차 높아지는 경향성을 보였다. 그러나 몇몇 문항들은 주변 문항보다 난이도가 지나치게 낮거나 높아지고 있는데, 이들 문항들은 문항 재배치 및 추가적인 문항 수정에 대한 통계적 근거 를 제공해준다.

시리즈 문항의 문항난이도 분석

Bayley-III에서는 실시지침은 동일하지만 발달에 따라 요구되는 
채점의 기준이 다른 문항들을 '시리즈 문항'으로 규정하여 한 번의 시행을 통해 동시에 채점될 수 있도록 구성하였다. 표현언어척도의 시리즈 문항의 난이도를 정리하면 Table 3과 같다. Table 3에 제시된 것처럼, 표현언어척도 시리즈 문항들은 모두 시리즈 순서에 따라 난 이도가 높아지는 경향을 볼 수 있었다. 이는 우리나라 영유아들에 게도 시리즈 문항의 순서를 유용하게 적용할 수 있음을 의미한다.

\section{월령단계별 문항통과율}

K-Bayley-III 표현언어척도가 한국어 및 우리 문화에 맞게 번안 되기는 하였지만 시작점 문항 및 기저선 문항은 미국 영유아들을 대상으로 설정된 기준을 그대로 사용하였다. 따라서 우리나라 기 저선 문항 배치의 적절성을 살펴보기 위하여, 월령 단계별 시작 문 항 통과율을 살펴보았으며 그 결과는 Table 4 와 같다. Table 4 에서 보듯이, 대부분의 월령 단계에서 시작점 문항은 $95 \%$ 이상의 문항 통과율을 보였고, 기저선 문항도 대체도 $90 \%$ 이상의 통과율을 보 이고 있어서 대체로 적절한 것으로 보인다. 다만, J, K, M을 비롯한 일부 월령 단계의 시작점 및 기저선 문항의 조정이 필요한 것으로 보인다.

\section{보충문항의 문항분석}

표현언어척도 원검사에서 삭제된 문항인 38 번과 40 번 문항을 대 체하기 위해서는 원문항과 동일하게 형태론을 다룬 문항이면서도 유사한 난이도의 문항으로 대체되어야 한다. 이를 위해 형태론을 다루는 표현언어척도 보충문항의 난이도를 살펴보았다. Table 5에 제시된 것처럼, 보충문항의 난이도는 대체로 $\mathrm{P}-\mathrm{Q}$ 단계에 해당할 만 큼 상당히 어려운 것으로 나타났다.

Table 3. Difficulty of series items

\begin{tabular}{lcc}
\hline Series item & Item no. & $b$ \\
\hline C-V combination series & 10 & -.475 \\
Naming objects series & 13 & -.106 \\
& 20 & .264 \\
Naming action pictures series & 27 & .560 \\
& 31 & .657 \\
Uses words appropriately series & 35 & .866 \\
& 37 & 1.062 \\
Naming picture series & 18 & -.136 \\
& 23 & .191 \\
Describes pictures series & 22 & .255 \\
& 28 & .592 \\
& 46 & 1.700 \\
& 47 & 1.825 \\
\hline
\end{tabular}

$b=$ difficulty parameter.

\section{신뢰도}

내적 일관성 신뢰도

K-Bayley-III 표현언어척도의 문항내적일관성 신뢰도를 확인하 기 위해 월령 단계별 Cronbach $\alpha$ 계수를 산출한 결과는 Table 6와 같다. K-Bayley-III 표현언어척도의 각 월령단계별 Cronbach $\alpha$ 계 수는 전반적으로 적절한 수준에 있는 것으로 나타났으며, 전체 평 균 Cronbach $\alpha$ 계수는 .77로 동질적인 문항으로 구성되어 있음을 보여주고 있다.

\section{재검사 신뢰도}

K-Bayley-III의 시간에 따른 안정성을 확인하기 위하여 재검사

Table 4. Percentage of correct response by age level

\begin{tabular}{lccc}
\hline Age level & Start point & Basal 1st ltem & Basal 2nd ltem \\
\hline A & 1.00 & 1.00 & 1.00 \\
B & 1.00 & 1.00 & .91 \\
C & 1.00 & 1.00 & .96 \\
D & 1.00 & 1.00 & 1.00 \\
E & 1.00 & .95 & 1.00 \\
F & 1.00 & .95 & .90 \\
G & 1.00 & .95 & 1.00 \\
H & 1.00 & 1.00 & 1.00 \\
I & .95 & .85 & 1.00 \\
J & .78 & .83 & .74 \\
K & .88 & 1.00 & .67 \\
L & .95 & 1.00 & .91 \\
M & .76 & .81 & .67 \\
N & .90 & 1.00 & .95 \\
O & .89 & .93 & .89 \\
P & .95 & .93 & .83 \\
O & .86 & .89 & .89 \\
\hline
\end{tabular}

Refer to Table 1 for age in months.

Table 5. Difficulty for additional items of expressive communication subtest

\begin{tabular}{|c|c|c|c|}
\hline Item & $b$ & $\begin{array}{l}\text { Expected age } \\
\text { level (mo) }\end{array}$ & $\begin{array}{l}\text { Actual age } \\
\text { level (mo) }\end{array}$ \\
\hline 1. Uses postpositional particles (nominal) & .78 & $N: 25-28$ & $0: 39-42$ \\
\hline 2. Uses negatives in two-word sentences & .54 & $N, 0: 27-29$ & P: 33-38 \\
\hline 3. Answers questions requiring choice & .26 & $0: 28-32$ & 0: 28-32 \\
\hline 4. Uses connective endings of causes & 1.48 & 0,P: $31-33$ & 0: 39-42 \\
\hline 5. Uses postpositional particles (locatives) & 1.60 & P: 33-38 & 0: $39-42$ \\
\hline 6. Uses past tense & 1.10 & P: 33-38 & 0: 39-42 \\
\hline 7. Uses coordinate clauses & 2.22 & P: 33-38 & $0: 39-42$ \\
\hline 8. Uses subordinate conjunctions & 2.02 & P: 33-38 & 0: 39-42 \\
\hline
\end{tabular}

$b=$ difficulty parameter. 
Table 6. Reliability of the expressive communication scale by age group

\begin{tabular}{lc}
\hline Age group & Cronbach a \\
\hline A & .727 \\
B & .604 \\
C & .615 \\
D & .264 \\
E & .392 \\
F & .674 \\
G & .905 \\
H & .775 \\
I & .736 \\
J & .911 \\
K & .854 \\
L & .894 \\
M & .919 \\
N & .914 \\
O & .954 \\
P & .947 \\
O & .924 \\
Average & .770 \\
\hline
\end{tabular}

신뢰도를 알아보았다. 참여 아동의 약 $4 \%$ 에 해당하는 15 명에게 $1-2$ 주일 간격으로 재검사를 실시한 결과, .98 의 매우 높은 신뢰도를 보 여 시간에 따른 안정성을 입증하였다.

\section{검사자 간 신뢰도}

K-Bayley-III 채점에서의 검사자에 따른 안정성을 확인하기 위하 여 검사자 간 신뢰도를 알아보았다. 참여 아동의 약 $5 \%$ 에 해당하는 19 명을 대상으로 검사하는 과정에서 각각 채점하여 신뢰도를 산출 한 결과, .997 의 매우 높은 검사자 간 신뢰도를 나타내었다.

\section{타당도}

내적 구조에 근거한 구인타당도

표현언어척도의 구인을 검증하기 위해, K-Bayley-III 하위 구인 간의 수렴타당도 및 변별타당도를 통해 실시하였다. 수렴타당도는 표현언어척도와 이론적으로 유사한 구인을 측정하는 수용언어척 도와 언어척도와의 높은 관련성을 통해 수렴 근거를 제공받게 도 며, 변별타당도는 표현언어척도와 이론적으로 다른 구인을 측정하 는 상위 구인인 인지척도 및 운동척도와 관련성이 높지 않으면 변 별 근거를 제공받는 것으로 가정하였다. 이를 위하여 본 연구에서 는 Bayley-III 미국 표준화 연구(Bayley, 2006)에서 사용한 방식과 유사하게 4가지 연령집단(0-6개월, 7-12개월, 13-25개월, 26-42개 월)으로 묶어서 살펴보았다. Table 7에 제시된 것처럼, 표현 언어척 도와 이론적으로 유사한 구인을 측정하는 상위 구인인 수용언어
Table 7. Inter-correlations of subtests ( $N=373$ )

\begin{tabular}{lrrrr}
\hline \multirow{2}{*}{ K-Bayley-III } & \multicolumn{4}{c}{ Age group of EC scale (mo;day) } \\
\cline { 2 - 5 } & $0 ; 16-6 ; 15$ & $6 ; 16-13 ; 15$ & $13 ; 16-25 ; 15$ & $25 ; 16-42 ; 15$ \\
\hline RC scale & $.704^{* *}$ & $.675^{* *}$ & $.814^{* *}$ & $.687^{* *}$ \\
Language scale & $.905^{* *}$ & $.953^{* *}$ & $.951^{* *}$ & $.938^{* *}$ \\
Cognitive scale & $.518^{* *}$ & $.476^{* *}$ & $.747^{* *}$ & $.529^{* *}$ \\
Motor scale & $.337^{* *}$ & $.473^{* *}$ & $.333^{* *}$ & $.618^{* *}$ \\
\hline
\end{tabular}

K-Bayley-III = Korean version of the Expressive Communication Scale of Bayley-III; $\mathrm{EC}=$ expressive communication scale; $\mathrm{RC}=$ receptive communication scale. ${ }^{* *} p<.01$.

$(r=.67-.81)$ 및 언어 $(r=.90-.95)$ 척도와는 높은 관련성을 보이며 수 렴타당도를 입증하였으며, 이론적으로 다른 구인을 측정하는 상위 구인인 인지( $r=.47-.74)$ 및 운동( $r=.33-.61)$ 척도와는 관련성이 상 대적으로 중간-낮은 관련성을 보여서 변별 타당도를 입증하였다.

\section{공인타당도}

K-Bayley-III 표현언어척도의 공인타당도를 알아보기 위하여 국 내에서 영유아의 언어진단평가도구로 널리 사용 중인 취학 전 아동 의 수용언어 및 표현언어 척도(PRES; Kim et al., 2003)와 맥아더-베 이츠 의사소통발달 평가(K M-B CDI; Pae \& Kwak, 2011) 중 유아 용 표현어휘와의 상관을 분석하였다. 본 검사의 참여아동 중 $10 \%$ 에 해당하는 30 명을 대상으로 공인타당도를 알아본 결과, PRES와 .847 의 상관을 보여 두 검사 간의 유의한 정적 관계를 의미하고, $\mathrm{K}$ M-B CDI와는 .921의 상관을 보여 두 검사 간의 매우 유의한 상관 성을 나타냈다.

\section{논의 및 결론}

본 연구는 Bayley-III 표현언어척도를 한국형으로 표준화하기 위 한 예비연구로서, 한국어 및 한국 문화에 적절하게 K-Bayley-III를 제작한 후 서울 및 경기지역에 거주하는 생후 16 일부터 42 개월 15 일에 해당하는 영유아를 대상으로 검사를 실시하였다.

본 연구의 결과에 따른 논의점을 살펴보면 다음과 같다. 첫째, 문 항 난이도를 살펴본 결과, K-Bayley-III 표현언어척도 문항은 대체 로 쉬운 문항부터 어려운 문항까지 고르게 분포되어 있었으며 비교 적 순차적으로 배치되어 있었다. 이 중에는 더 많은 표본을 가지고 전국 단위로 표준화연구를 진행하였을 때 추가로 수정되고 재배치 할 문항도 존재할 것이다. 또한 월령단계별 시작점 문항 및 기저선 문항의 적절성을 파악하기 위하여 문항 통과율을 살펴본 결과, 원 척도의 시작점 및 기저선 문항을 한국 영유아에게 적용하기에 무리 가 없는 것으로 나타났다. 그리고, 삭제된 문항들을 대체하기 위해 
한국형 베일리 영유아 발달검사 제3판 표현언어척도 예비연구 • 이지연 외

제작된 보충문항들은 Bayley-III에는 포함되어 있지 않은 한국어의 발달 특성을 적절한 난이도로 측정할 수 있는 것으로 확인되었다.

그러나, 일부 문항들은 재배치 및 문항 수정의 필요성이 발견되 었다. 난이도 순서에 따라 문항을 재배열했을 때 원척도보다 세 문 항 이상 앞으로 이동한 문항들로 문항 17번(놀이 상호작용에 참여 하기), 문항 24 번('예/아니오' 질문에 대답하기), 문항 30 번(대명사 사용하기) 등이 있었으며, 원척도보다 세 문항 이상 뒤로 이동한 문 항들로 문항 13 번(자음-모음 조합시리즈: 4 개), 문항 20 번(사물 명 명하기 시리즈: 1 개), 문항 44 번(문항 위치부사어 사용하기) 등이 있 었다. 이러한 결과는 우리와 같이 동양권 문화에 속하는 대만에서 진행된 Bayley-III 연구 결과(Yu et al., 2013)와 유사하기도 하고 차 이가 나기도 한다. 먼저 유사한 측면을 살펴보면, 6-24개월 영유아 를 대상으로 진행된 대만 Bayley-III 연구에서도 낮선 검사자 앞에 서 언어적 발화(예, 재잘거리며 표현하기, 유사한 단어 사용하기)를 측정하는 표현 언어 문항에서 미국 규준에 비해 더 낮은 검사를 얻 었다. 이는 대만의 영유아들이 안전과 감염의 이유로 새로운 환경 이나 낮선 이에 대한 노출이 적기 때문에 낮선 장소에서 낮선 검사 자와 하는 검사 상호작용이 아동의 수행에 영향을 미쳤을 것으로 설명하였다(Yu et al., 2013). 한국 영유아들도 24개월 이전에 언어 적 발화를 측정하는 문항 13 번(자음-모음 조합시리즈: 4 개), 문항 20 번(사물 명명하기 시리즈: 1 개)에서 유독 난이도의 차이를 보였 는데, 이는 베일리 2판으로 한국 영유아의 수행을 살펴본 Chung, Lee와 Park (1993), Cho와 Park (2004)의 연구에서도 언어반응이 강조되는 문항에서 미국 규준에 비해 수행이 낮게 나타난 것과 일 치하는 결과이다. Bloom (1993)에 따르면, 언어와 정서는 동일한 인 지 자원을 놓고 서로 경쟁을 하므로 정서의 표현에 많은 주의와 자 원을 사용하게 되면 어휘 획득에 사용될 주의와 자원이 상대적으 로 줄어들게 된다고 보고하고 있는데, 낮선 검사 상황에서 느껴질 수 있는 불안한 정서가 아동의 발화를 억제했을 것으로 해석된다. 두 번째로 대만 연구와 차이가 나는 측면을 살펴보면, 대만 BayleyIII 연구에서는 낮선 이와의 상호작용을 포함하는 문항(예, 일상 놀 이에 참여하기, 다른 사람의 주의 돌리기, 놀이 상호작용 시작하기) 에서도 모두 미국 규준에 비해 낮은 점수를 얻은 반면, 한국 영아 들은 사회적 상호작용을 측정하는 문항 17 번(놀이 상호작용에 참 여하기), 문항 24 번('예/아니오' 질문에 대답하기)에서는 오히려 미 국 규준보다 더 높은 점수를 얻었다. 대만 부모들은 영아의 일상에 서 성장이 중요하다고 믿기에 놀이보다는 먹는 것과 자는 것을 더 강조하는 양육 관습을 가진 반면에(Yu et al., 2013), 한국 부모들은 전통적으로 단동십훈과 같이 영아를 대상으로 상호작용적 놀이 를 중요시하기 때문인 것으로 해석된다. 이는 K-Bayley-III 인지척
도의 놀이문항에서 나타난 반응 패턴과 유사한 것으로, 미국에서 는 자기 관련 짓기 놀이가 먼저 발달하는 반면, 한국에서는 타인 관 련 짓기 놀이가 자기 관련 짓기 놀이보다 먼저 나타나는 특성을 보 였다(Oh, Bang, \& Lee, 2014).

둘째, K-Bayley-III 표현언어척도의 신뢰도를 확인하기 위하여 내 적일관성 신뢰도, 검사-재검사 신뢰도, 채점자간 신뢰도를 살펴보 았다. K-Bayley-III 표현언어척도는 평균 Cronbach $\alpha$ 가 .77로 동질 적인 내용으로 구성된 양호한 검사임이 확인되었으며, 검사-재검사 신뢰도와 평정자간 신뢰도 역시 각각. 98 과 .99 로 시간 및 검사자에 따른 안정성도 우수한 검사임이 확인되었다. 따라서 K-Bayley-III 표현언어척도는 한국 영유아의 언어능력을 신뢰롭게 평가할 수 있 는 도구로 증명되었다. 다만, 일부 어린 연령 단계의 내적 일관성에 서 낮게 나왔는데, 이는 Cronbach $\alpha$ 값이 예비연구에 참여한 20명 내외의 표집에서 산출된 값으로 몇 명의 극단치에서 나온 높은 문 항 분산값이 내적 일관성 수치를 낮추었을 가능성을 배제할 수 없 다. 이에 표준화 연구에서는 각 연령집단 당 100 명의 참여자를 대상 으로 검사를 실시하므로 이들 단계에 대한 내적 일관성 계수에 대 한 검토가 요구된다.

셋째, K-Bayley-III 표현언어척도의 타당도를 확인하기 위해 내적 구조에 근거한 구인타당도와 공인타당도를 살펴보았다. K-BayleyIII 표현언어척도는 이론적으로 관련성이 높은 상위 구인인 언어척 도와는 높은 상호상관을 보여 수렴 타당도를 입증한 반면, 이론적 으로 관련성이 중간 정도인 상위 구인인 인지척도와는 중간 정도의 상호상관을, 그리고 이론적으로 관련성이 다소 낮은 운동척도와 는 상대적으로 다소 낮은 상관을 보여 변별타당도를 입증하였다. 또한 기존의 인정받는 언어평가도구인 PRES 및 $\mathrm{K} \mathrm{M-B} \mathrm{CDI와} \mathrm{각}$ 각 .847과.921로 정적으로 높은 상관을 보여주어 K-Bayley-III 표현 언어척도의 공인타당도를 입증하였다. 따라서, K-Bayley-III 표현언 어척도는 측정 연령의 확장 및 정교한 전문가의 검사, 통합적인 발 달검사라는 차별점에도 불구하고 기존의 언어평가도구와 유사한 구인을 측정하는 검사임이 입증되었다.

본 연구의 자료는 K-Bayley-III 표준화 연구를 위한 기초 자료가 될 뿐만 아니라 한국 아동의 언어 발달을 비교 문화적인 관점에서 살펴볼수 있는 기회가 될 것이다.

본 연구의 제한점과 후속 연구를 위한 제언들은 다음과 같다. 첫 째, 본 연구는 K-Bayley-III 예비연구로서 월령 단계별로 서울 경기 지역의 영유아 20 명 내외의 표집을 하였으므로 언어발달이론 및 난이도 측면에서 확연하게 차이가 나는 문항 위주로 분석 및 수정 을 하였다. 추후 표준화 연구에서는 전국에 거주하는 영유아를 대 상으로 각 월령별로 100 여 명씩 표집하도록 제안되므로, 문항의 난 
이도 및 시작점 문항.기저선 문항의 통과율을 확인하고 문항의 재 배열을 정교하게 검토할 것을 제안한다. 더불어 본 연구에서 추가 된 보충문항의 난이도를 재확인하여 추가 배치 문항을 확정할 것 을 제안한다. 둘째, 추후 연구에서는 언어 관련 다양한 임상집단-언 어발달지체, 조음음운장애, 자폐스펙트럼장애, 단순언어장애 등을 포함하여 언어장애를 판별할 수 있는 진단기준점을 산출하여 진단 도구로써의 유용성을 검증할 것을 제안한다.

\section{REFERENCES}

Acton, B. V., Biggs, W. S., Creighton, D. E., Penner, K. A., Switzer, H. N., Thomas, J. H. P., ... Robertson, C. M. (2011). Overestimating neurodevelopment using the Bayley-III after early complex cardiac surgery. Pediatrics, 128, e794-e800.

Aylward, G. P. (2009). Developmental screening and assessment: what are we thinking? Journal of Developmental \& Behavioral Pediatrics, 30, 169-173.

Bayley, N. (1993). Bayley scales of infant development (2nd ed.). New York: Psychological Corp.

Bayley, N. (2006). Bayley scales of infant and toddler development (3rd ed.). New York: Psychological Corp.

Bloom, L. (1993). The transition from infant to language: acquiring the power of expression. New York: Cambridge University Press.

Chang, Y. K. (2004b). Early lexical development of Korean infants: 8-17 months. Korean Journal Psychology, 23, 77-99.

Cho, B. H., \& Park, H. W. (2004). The standardization study (1) of Korean Bayley Scales of Infant Development (K-BSID-2) analyses of Korean infants' performance of K-BSID-2 in terms of demographical variables. Korean Journal of Developmental Psychology, 17, 191-206.

Cho, M. H. (1982). Language acquisition studies of Korean children: strategy model. Seoul: Seoul National University Publishing.

Chung, M. J., Lee, E. H., \& Park, K. J. (1993). Preliminary study for the standardization of the Bayley Scales of Infant Development for Korean Infants. Korean Journal of Child Studies, 14, 5-21.

Esteban, F. J., Padilla, N., Sanz-Cortés, M., de Miras, J. R., Bargalló, N., Villoslada, P., ... Gratacós, E. (2010). Fractal-dimension analysis detects cerebral changes in preterm infants with and without intrauterine growth restriction. Neuroimage, 53, 1225-1232.

Kang, B. M. (2008). On the semantic differences of the two plural forms in Korean. Language and Information, 12, 115-137.

Kim, Y. T., Kim, K. H., Yoon, H. R., \& Kim, H. S. (2003). Sequenced Language Scale for Infants (SELSI). Seoul: Special Education Publishing.

Kim, Y. T., Sung, T. J., \& Lee, Y. K. (2003). Preschool Receptive-Expressive Language Scale (PRES). Seoul: Seoul Community Rehabilitation Center.

Moore, T., Johnson, S., Haider, S., Hennessy, E., \& Marlow, N. (2012). Relationship between test scores using the second and third editions of the Bayley Scales in extremely preterm children. Journal of Pediatrics, 160, 553558.

Oh, S. K., Bang, H. J., \& Lee, S. H. (2004). A preliminary study for the standardization of the Korean Bayley Scale of Infant and Toddler Development, Third Edition - Cognitive Scale. Korean Journal of Developmental Psychology, 27, 117-140.

Pae, S. Y., \& Kwak, K. J. (2011). Korean version of the MacArthur-Bates Communicative Development Inventories (K M-B CDI). Seoul: Mind Press.

Pence, K., \& Justice, L. (2008). Language development from theory to practice. Upper Saddle River, NJ: Pearson Merrill Prentice Hall.

Reuner, G., Fields, A. C., Wittke, A., Löpprich, M., \& Pietz, J. (2013). Comparison of the developmental tests Bayley-III and Bayley-II in 7-monthold infants born preterm. European Journal of Pediatrics, 172, 393-400.

Seong, T. J. (2001). Understanding and applying item response theory. Seoul: Science of Education.

Seong, T. J. (2004). Theories and models of making and analyzing items. Seoul: Hakjisa.

Walker, K., Badawi, N., Halliday, R., \& Laing, S. (2010). Brief report: Performance of Australian children at one year of age on the Bayley Scales of Infant and Toddler Development (Version III). Australian Educational and Developmental Psychologist, 27, 54-58.

Yu, Y. T., Hsieh, W. S., Hsu, C. H., Chen, L. C., Lee, W. T., Chiu, N. C., ... Jeng, S. F. (2013). A psychometric study of the Bayley Scales of Infant and Toddler Development-3rd Edition for term and preterm Taiwanese infants. Research in Developmental Disabilities, 34, 3875-3883. 
Appendix 1. K-Bayley-II표현언어척도의 문항 난이도 및 언어발달이론에 따른 최종 문항 배열 및 Bayley-III 원 문항과의 비교

\begin{tabular}{|c|c|c|c|c|c|}
\hline \multirow{2}{*}{ 단계 } & \multicolumn{3}{|c|}{ 미국판 Bayley-III 원문항 } & \multicolumn{2}{|r|}{ K-Bayley 문항 } \\
\hline & 문항 번호 & 문항 내용 & 비고 & 문항번호 & 문항 내용 \\
\hline \multirow{6}{*}{$\begin{array}{l}\text { A/B/C/D } \\
(16 d .-4 m .) \\
E / F / G / H \\
(4-10 m .)\end{array}$} & 1 & Undifferentiated Throaty Sounds (미분화된 목소리 내기) & & 1 & 미분화된 목소리 내기 \\
\hline & 2 & Social Smile (사회적 미소짓기) & & 2 & 사회정 미소짓기 학히기 \\
\hline & 3 & Vocalizes Mood (기분을 소리내어 표현하기) & & $\overline{3}$ & 기분을 소리내어 표현하기 \\
\hline & 4 & Undifferentiated Nasal Sounds (미분화된 비음소리 내기) & & 4 & 미분화된 비음소리 내기 \\
\hline & 5 & Social Vocalizing or Laughing (사회적 발성을 하거나 웃기) & & 5 & 사회적 발성을 하거나 웃기 \\
\hline & 6 & 2 Vowel Sounds (모음 2개 소리내기) & & 6 & 몾음 2개 소리내기 \\
\hline \multirow[t]{2}{*}{ I (11-13m.) } & 8 & 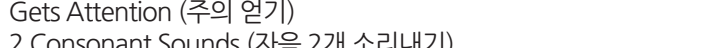 & & 7 & $\begin{array}{l}\text { 주의 얻기 } \\
\text { 자으 개개리내기 }\end{array}$ \\
\hline & 9 & 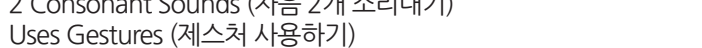 & & $\begin{array}{l}8 \\
9\end{array}$ & 제스처 사용하기 \\
\hline \multirow[t]{4}{*}{ J (13-16m.) } & 10 & $\begin{array}{l}\text { Consonant-Vowel Combination Series: } 1 \text { Combination } \\
\text { (자음-모음 조합 시리즈: 1개) }\end{array}$ & & 11 & 일상놀이에 참여하기 \\
\hline & 11 & Participates in Play Routine (일상놀이에 참여하기) & & 10 & 자음-모음 조합 시리즈: 1개 \\
\hline & 12 & Jabbers Expressively (재잘거리며 표현하기) & & 12 & 재잘거리며 표현하기 \\
\hline & 13 & $\begin{array}{l}\text { Consonant-Vowel Combination Series: } 4 \text { Combination } \\
\text { (자음-모음 조합 시리즈: 4개) }\end{array}$ & & 13 & 자음-모음 조합 시리즈: 4개 \\
\hline \multirow[t]{3}{*}{ K (16-19m.) } & 14 & Uses One-Word Approximations (유사 단 단어 사용하기) & & 14 & 유사 단 단어 사용하기 \\
\hline & 15 & Directs Attention of Other (다른 사람의 주의 돌리기) & & 15 & 다른 사람의 주의 돌리기 \\
\hline & 16 & Imitates Word (단어 모방하기) & 부분 수정된 문항 & 16 & 단어 모방하기 \\
\hline \multirow[t]{3}{*}{ L (19-22m.) } & 17 & Initiates Play Interaction (놀이 상호작용 시작하기) & & 17 & 놀이 상호작용 시작하기 \\
\hline & 18 & $\begin{array}{l}\text { Uses Words Appropriately Series: } 2 \text { Words } \\
\text { (단어 적절하게 사용하기 시리즈: } 2 \text { 개) }\end{array}$ & 부분 수정된 문항 & 18 & 단어 적절하게 사용하기 시리즈: 2개 \\
\hline & 19 & $\begin{array}{l}\text { Uses Word to Make Wants Known (단어를 사용하여 원하는 } \\
\text { 것 표현하기) }\end{array}$ & 부분 수정된 문항 & 19 & 단어를 사용하여 원하는 것 표현하기 \\
\hline \multirow[t]{3}{*}{$\mathrm{M} / \mathrm{N}(22-28 \mathrm{~m})}$. & 20 & Names Ōbject Series: 1 Object (사물 명명하기 시리즈: 1개) & & 20 & 사물 명명하기 시리즈: 1개 \\
\hline & 21 & Combines Word and Gesture (단어와 제스처 함께 사용하기) & & 21 & 단어와 제스처 함께 사용하기 \\
\hline & 22 & Names Picture Series: 1 Picture (그림 명명하기 시리즈: 1개) & 붑붑숫정된둔함항 & 22 & 그림 명명하기 시리즈: 1 개 \\
\hline \multirow[t]{4}{*}{$\mathrm{O}(28-32 \mathrm{~m})}$. & 23 & $\begin{array}{l}\text { Uses Words Appropriately Series: } 8 \text { Words (단어 적절하게 } \\
\text { 사용하기 시리즈: 8개) }\end{array}$ & 부분 수정된 문항 & 23 & 절하게 사용하기 시리즈: 8개 \\
\hline & 24 & $\begin{array}{l}\text { Answers Yes or No Verbally in Response to Questions } \\
\text { ('예/아니오' 질문에 대답하기) }\end{array}$ & 부분 수정된 문항 & 24 & '예/아니오' 질문에 대답하기 \\
\hline & 25 & Imitates a Two-Word Utterance (두 단어 문장 모방하기) & & 25 & 두 단어 문장 모방하기 \\
\hline & 26 & Uses a Two-Word Utterance (두 단어 문장 사용하기) & 부분 수정된 문항 & 26 & 두 단어 문장 사용하기 \\
\hline \multirow{3}{*}{$P(33-38 m)}$. & 27 & Names Object Series: 3 Object (사물 명명하기 시리즈: 3개) & & 27 & 사물 명명하기 시리즈: 3 개 \\
\hline & 28 & Names Picture Series: 3 Picture (그림 명명하기 시리즈: 3개) & & 28 & 그림 명명하기 시리즈: 3개 \\
\hline & 29 & Uses Multiple-Word Utterances (세 단어 이상 문장 사용하기) & 붑붑 숫정된 문항 & 29 & 세 단어 이상문장 사용하기 \\
\hline \multirow[t]{19}{*}{ Q (39-42m.) } & $\begin{array}{l}30 \\
31\end{array}$ & $\begin{array}{l}\text { Uses Pronouns (대명사 사용하기) } \\
\text { Names Action Picture Series: } 1 \text { Picture (동작 그림 명명하기 } \\
\text { 시리즈: 1개) }\end{array}$ & $\begin{array}{l}\text { 부분 수정된 문항 } \\
\text { 부분 수정된 문항 }\end{array}$ & $\begin{array}{l}30 \\
31\end{array}$ & $\begin{array}{l}\text { 대명사 사용하기: 나, 내, (이,저,그)것 } \\
\text { 동작 그림 명명하기 시리즈: } 1 \text { 개 }\end{array}$ \\
\hline & 32 & Poses Multiple-Word Questions (다 단어 질문 만들기) & 부분 수정된 문항 & 32 & 다 단어 질문 만들기 \\
\hline & 33 & Makes a Contingent Utterance (관련된 말로 반응하기) & & 33 & 관련된 말로 반응하기 \\
\hline & 34 & Uses Verb + ing (진행형 동사 사용하기) & & 34 & 진행형 동사 사용하기 \\
\hline & 35 & $\begin{array}{l}\text { Names Action Picture Series: } 3 \text { Picture (동작 그림 명명하기 } \\
\text { 시리즈: } 3 \text { 개) }\end{array}$ & 부분 수정된 문항 & 35 & 동작 그림 명명하기 시리즈: 3개 \\
\hline & 36 & Uses Different Word Combinations (다양한 단어 조합 사용하기) & 부분 수정된 문항 & 36 & 다양한 단어 조합 사용하기 \\
\hline & 37 & $\begin{array}{l}\text { Names Action Picture Series: } 5 \text { Picture (동작 그림 명명하기 } \\
\text { 시리즈: } 5 \text { 개) }\end{array}$ & 부분 수정된 문항 & 37 & 동작 그림 명명하기 시리즈: 5개 \\
\hline & 38 & Uses Plurals (복수형 사용하기) & 한국어에서 나타나 & 39 & '무엇'과 '어디' 질문에 대답하기 \\
\hline & & & 로 삭제됨 & & \\
\hline & 39 & $\begin{array}{l}\text { Answers What and Where Questions ('무엇'과 ‘어디' 질문에 } \\
\text { 대답하기) }\end{array}$ & & 41 & 4가지 색깔 명명하기 \\
\hline & 40 & Uses Possessives (소유격 사용하기) & $\begin{array}{l}\text { 한국어에서 나타나 } \\
\text { 지 않는 문항으 } \\
\text { 로 삭제됨 }\end{array}$ & 42 & 질문에 논리적으로 대답하기 \\
\hline & 41 & Names 4 Colors (4가지 색깔 명명하기) & & 45 & 현재 진행형 사용하기 \\
\hline & 42 & $\begin{array}{l}\text { Answers Questions Logically (Related to Functions) } \\
\text { (질문에 논리적으로 대답하기) }\end{array}$ & 보충문항 추가 $\rightarrow$ & 보충 5 & $\begin{array}{l}\text { 도구격 및 처소격 조사( 에서/ } \\
\text { 한테/ 로) 사용하기 }\end{array}$ \\
\hline & 43 & Tells How an Object is Used (사물의 용도 말하기) & 보충문항 추가 $\rightarrow$ & 보충 4 & 이유 연결어미( 서) 사용하기 \\
\hline & 44 & Uses Prepositions (위치 부사어 사용하기) & 부분 수정된 문항 & 43 & 사물의 용도 말하기 \\
\hline & 45 & Uses Present Progressive Form (현재 진행형 사용하기) & 부분 수정된 문항 & 44 & 위치 부사어 사용하기 \\
\hline & 46 & $\begin{array}{l}\text { Describes Picture Series: 4-5 Word Sentences (그림 묘사하기 } \\
\text { 시리즈: 4-5개 단어로 된 문장 말하기) }\end{array}$ & & 46 & $\begin{array}{l}\text { 그림 묘사하기 시리즈: } 4-5 \text { 개 } \\
\text { 단어로 된 문장 말하기 }\end{array}$ \\
\hline & 47 & $\begin{array}{l}\text { Describes Picture Series: Uses Past Tense (그림 묘사하기 시리즈: } \\
\text { 과거 시제로 말하기) }\end{array}$ & & 47 & $\begin{array}{l}\text { 그림 묘사하기 시리즈: 과거 시제로 } \\
\text { 말하기 }\end{array}$ \\
\hline & 48 & $\begin{array}{l}\text { Describes Picture Series: Uses Future Tense (그림 묘사하기 } \\
\text { 시리즈: 미래 시제로 말하기) }\end{array}$ & & 48 & $\begin{array}{l}\text { 그림 묘사하기 시리즈: 미래 시제로 } \\
\text { 말하기 }\end{array}$ \\
\hline
\end{tabular}




\section{국문초록}

\section{한국형 베일리 영유아 발달검사 제3판 표현언어척도 예비연구}

이지연 1 김영태 ${ }^{2} \cdot$ 방희정 ${ }^{3} \cdot$ 이순행 3

${ }^{1}$ 이화여자대학교 심리학과 발달 및 발달임상전공, ${ }^{2}$ 이화여자대학교 일반대학원 언어병리학과, ${ }^{3}$ 이화여자대학교 대학원 발달 및 발달임상 심리학과

배경 및 목적: 본 연구는 Bayley-III 표현언어척도를 한국형으로 표준화하기 위한 예비연구로서, 한국어 발달 및 한국 문화 특성을 반 영하는 한국형 베일리 영유아 발달검사 제3판(K-Bayley-III) 표현언어척도 예비연구본을 제작하고, 문항분석 및 타당도와 신뢰도를 검 증하여 국내 적용가능성을 살펴보고자 하였다. 방법: Bayley-III 표현언어척도 원문항 48 개 외에 보충문항 8개를 추가 제작하여 K-Bayley-III 표현언어척도 예비연구본을 제작하고 수도권에 거주하는 생후 16 일 42개월 15일의 영유아 373 명을 대상으로 예비연구를 실시 하였다. 결과: 첫째, 문항난이도 및 월령별 문항통과율을 통해 문항분석을 살펴본 결과, 전체적으로 쉬운 문항부터 어려운 문항까지 적 절히 구성되었으며, 난이도가 적절하지 않은 문항은 재배치, 수정, 또는 삭제되고 대체되었다. 월령단계별 기저선 문항도 $90 \%$ 의 통과율 을 보여 전반적으로 적절하였다. 둘째, 문항내적일관성 및 재검사, 검사자간 신뢰도를 검증한 결과, 문항내적일관성은 양호한 수준이었 고 재검사 및 검사자 간 신뢰도 모두 매우 높은 수준이었다. 셋째, 구인타당도 및 공인타당도를 살펴본 결과, 표현언어척도는 언어척도 및 운동척도와 각각 수렴타당도와 변별타당도를 보여 구인타당도를 입증하였고, 기존의 언어검사도구와도 높은 상관성을 보여 공인타 당성을 확인하였다. 논의 및 결론: K-Bayley-III 표현언어척도는 국내 영유아의 표현언어발달을 측정하기에 양호한 검사로 확인되었다. 다만, 한국의 언어발달 특성을 반영하지 못하는 몇몇 문항들은 문항 재배치 및 내용 수정이 요구되어 K-Bayley-III 표현언어척도 표준 화본 마련을 위한 제안을 하였다.

핵심어: 한국형 베일리 영유아 발달검사 제3판(K-Bayley-III), 표현언어척도, 문항분석, 신뢰도, 타당도

본 연구는 2012년 보건복지부 사회서비스 R\&D ‘한국형 영유아 발달검사 서비스 개발’ 연구비 지원에 의해 이루어짐.

본 연구는 제1저자의 이화여자대학교 석사학위 논문 자료를 기초로 하였음(2014).

\section{참고문헌}

강범모 (2008). 두 가지 복수형의 의미 차이에 대하여. 언어와 정보, 12, 115-137.

김영태, 김경희, 윤혜련, 김화수 (2003). 영유아 언어발달검사(SELSI). 서울: 도서출판 특수교육.

김영태, 성태제, 이윤경 (2003). 취학 전 아동의 수용언어 및 표현언어 척도(PRES). 서울: 서울장애인종합복지관.

배소영, 곽금주 (2011). 한국판 맥아더-베이츠 의사소통발달평가(KM-B CDI). 서울: 마인드프레스.

성태제 (2004). 문항제작 및 분석의 이론과 실제. 서울: 학지사.

성태제(2001). 문항반응이론의 이해와 적용. 서울: 교육과학사.

오수경, 방희정, 이순행 (2014). 한국형 베일리 영유아 발달검사 3판 인지척도 예비 연구. 한국심리학회지: 발달, 27, 117-140.

장유경 (2004b). 한국 영아의 초기 어휘발달: 8개월-17개월. 한국심리학회지: 일반, 23, 77-99.

정문자, 이은혜, 박경자 (1993). 베일리 유아발달척도의 한국표준화를 위한 예비연구. 아동학회지, 14, 5-21.

조명한 (1982). 한국아동의 언어획득 연구: 책략 모형. 서울: 서울대학교 출판부.

조복희, 박혜원 (2004). 한국 Bayley 영유아 발달검사(K-BSID-2) 표준화연구(1): 지역, 성별 및 모의 교육수준에 따른 K-BSID-2 수행분석. 한국심리

학회지: 발달, 17, 191-206. 